\title{
The Effect of Rose Aromatherapy on Reducing The Post-Operative Pain Scale in Aisyiyah Padang Hospital, West Sumatera, Indonesia
}

\author{
Melti Suriya*, S. Zuriati \\ Lecturer, STIKes Alifah Padang, Indonesia \\ *Correspondence E-mail : suriyamelti@gmail.com*; zuriati3781@gmail.com
}

\begin{abstract}
The World Health Organization (WHO) data in 2012 experienced an increase of 148 million people globally, regarding the post-operative pain is concerned. In the year 2012, the prevalence reached 1.2 million people in Indonesia and was estimated at $32 \%$ to be exact. It has been found that postoperative patients complained of pain incidence with an average pain scale of 7-9. The purpose of this study was to determine the effect of rose aroma therapy on reducing pain scale in post-operative patients in the Care Room of Aisyiyah Hospital, Padang in 2018.

The design of this study was Quasi Experiment with the type of pretest and posttest perspectives taken two groups into account. The sample of this study was Post Laparatomi at Aisyiyah Hospital Padang with the technique "Accidental Sampling". The sample of this study was 30 people for the Aromatherapy rose group. Statistical test used for the study was the Independent $t$ test.

Based on the results of this study the mean postoperative pain scale before being given aromatherapy rose is 5.87 and after that is 3.76 , respectively with a p-value of 0.000 . It can be concluded that the aroma of rose therapy can reduce the pain scale of postoperative patients. It is recommended for nurses in handling the patients having pain after being operated by providing pain management, namely aromatherapy roses.
\end{abstract}

Keywords: Post Surgery, Pain, Aromatherapy Rose

\section{Introduction}

The treatment measures like surgery, use of invasive methods by opening or displaying the parts of the body to be handled. (Brunner \& Suddarth, 2002). Based on the results of the study, one of the patient's postoperative wound healing was lacking early mobilization due to perceived pain (Suriya, 2017).

Improper and accurate management of postoperative pain will increase the risk of complications, increase the cost of care to extend the day of care, and slow down the healing process. Another impact was due to the postoperative pain that is not reduced will cause debilitation (weaken motivation or energy), inhibit the quality of life and lead to depression (Black \& Hawk, 2005).

In addition, the prolonged postoperative pain will trigger a stress response and sympathetic nerve activity, causing tissue breakdown, metabolic rate, coagulation, and water retention. Pain management should include (except drug treatment): 
music, relaxation complement pain medicine (Datak, 2008).

Nurses are health professionals who always be with the patients continuously and have an important role in managing patients with postsurgical pain. Nurses not only collaborate with other health teams, but they can identify and provide nursing interventions and evaluate the implementation. Dealing with pain management is one of the interventions provided by nurses in helping patients handle and control pain. (Potter \& Perry, 2012).

Nursing interventions performed by nurses in reducing or eliminating postoperative pain are by pharmacological collaboration. Pharmacological intervention by giving analgesics to patients, while nonpharmacological interventions have not been widely used by nurses to reduce post-surgical pain and are reported to have a very low risk (Smeltzer \& Bare, 2002).

Non-pharmacological intervention is a complementary therapy in reducing postoperative pain and not as a major substitute for analgesic therapy. The Agency for Health Care Policy and Research (AHCPR) recommends that a combination of pharmacological and non-pharmacological interventions is the best way to control postoperative pain (Datak, 2008).

Aromatherapy is one of the potential methods of reducing perioperative pain. Aromatherapy is a form of complementary and alternative medicine that uses essential oils to affect a patient's mood and health. In addition to music, relaxation, guided imagery, and massage, aromatherapy has been used by nurses as part of a holistic approach to minimize preoperative anxiety (Lo, et al., 2016)

Many common plant oils are commonly utilized as anxiolytics. These include lavender (Lavandula angustifolia), rose (Rosa damascena), bergamot (Citrus aurantium, subsp bergamia), and sandalwood (Santalum album) (Lo et al., 2016). Aromatherapy refers to the use of drugs or therapies for essential oils absorbed through the skin or olfactory system. Although many claims have been made regarding the benefits of aromatherapy, most studies have focused on its use to manage depression, anxiety, muscle tension, sleep disturbances, nausea, and pain. Although aromatherapy is commonly used and has been carried out for centuries, several high-quality empirical reviews have examined its effectiveness in reducing pain.

Giving topical rose oil causes a decrease in pain intensity. Rose oil also increases the functional ability of these patients in contrast to no intervention. Rose oil is one of the most popular topical preparations recommended in traditional Persian medicine for pain management, especially essential oils from Rosa damascena, trapped in fixed oil (almond oil). Sadeghi, et al. reported that massage therapy with rose oil in 25 volunteers with primary dysmenorrhea had a significant effect on pain reduction (Shirazi et al., 2017).

\section{Methodology}

Foot soaking in warm water is one of the therapies of hypertension which is useful to dilate blood vessels, improve blood circulation and trigger nerves of the feet (Batjun, 2015).

This research is a type of quantitative research with a design that is used "Quasi Experiment". Two groups treatments were carried out namely, Aromatherapy Rose and relaxation techniques by grouping the experimental group with then pretest and posttest after being given treatment. This research was carried out in Aisyiyah Hospital in the surgical room in 2018. The collection was carried out by accidental sampling as many as 30 respondents. Data collection was directly observed. The dependent variable in this study is the pain scale and the independent variable is the aroma of rose therapy. Data analysis was carried out by Univariate looking at each variable and bivariate using parametric tests namely, paired $t$-test.

\section{Results}

From the table1, the mean postoperative pain scale with $P$-value 0,000 is obtained. Whereas in the relaxation technique group with $\mathrm{P}$-value 0.002 , where there is a 
difference between relaxation techniques and rose aromatherapy, and more effective is the aroma therapy with a mean difference of 2 , while in the relaxation group 1.17 .

Table 1. Effect of pain scale pre and post giving Rose scent therapy to post-operative

\begin{tabular}{|l|l|c|c|c|c|c|}
\hline \multicolumn{2}{|c|}{ Group } & \multirow{2}{*}{ N } & Mean & SD & T & P-Value \\
\hline Rose Therapy & Pre & \multirow{2}{*}{15} & 5.87 & 1.146 & \multirow{2}{*}{4.930} & 0.000 \\
\cline { 2 - 7 } & Post & 3.76 & 0.834 & 2.172 & 2.256 & 0.002 \\
\hline Relaxtion Tecnique & Pre & 15 & 5.75 & 1.172 & \\
\hline
\end{tabular}

\section{Discussion}

Based on the results of the study found that there is the effect of rose aromatherapy to reducing the pain scale of postoperative. This is in line with research (Shaheen E. Lakhan et al. 2016). The Effectiveness of Aromatherapy in Reducing Pain: A Systematic Review and Meta-Analysis there are aromatherapy can successfully treat pain when combined with conventional treatments.

Aromatherapy refers to the medicinal or therapeutic use of essential oils absorbed through the skin or olfactory system. Some studies suggest that olfactory stimulation related to aromatherapy can result in immediate reduction in pain, as well as changing physiological parameters such as pulse, blood pressure, skin temperature, and brain activity. Although the benefits remain controversial, many patients and healthcare providers are attracted to aromatherapy because of its low cost and minimal side effects. Aromatherapy is most often used topically, or through inhalation. Smell and a sense of touch the $s$ produced by this oil can improve Pain Care.

Although aromatherapy is generally used and has has been done for centuries, some high quality empirical reviews has examined its effectiveness in reducing pain. These results indicate that aromatherapy Pain Research and Treatment should be considered a safe addition to current pain management procedures as no adverse effects were reported in any of the included studies. Additionally, the cost associated with aromatherapy is far less than the cost associated with standard pain management treatment. Although the present meta-analysis indicates a large positive effect for the use of aromatherapy for pain management, the sample size is small. Given the prevalence of aromatherapy, more research is necessary to fully understand clinical applications for its use.

Aromatherapy, then, has an important role to play in holistic nursing practice, especially in time-limited situations such as the preoperative wait before ambulatory surgery; however, as demonstrated by improvement in the control group, nursing care itself helps to alleviate preoperative anxiety. Caring therapeutic use of the self as well as holistic interventions such as hypnosis, guided imagery, music, touch, and aromatherapy is essential when dealing with this common and distressing problem for most surgical patients ( $\mathrm{Ni}$ et al., 2013)

The exact mechanism of rose oil for pain relief is not clear, but possible mechanisms involve stimulating the olfactory system and reduction of sympathetic activity, increase in parasym- pathetic activity, and release of endorphin by Rosa damascena essential oil, which results in an increase in pain threshold. Although Hongratanaworakit has reported similar effects with dermal absorption of rose oil without olfactory stimulation, he has demonstrated that rose oil molecules enter the blood stream by dermal absorption. In this study, it was observed that rose oil had physiological and psychological relaxation, analgesic and anti- anxiety effects. To obtain conclusive results on the efficacy and safety of rose oil, further clinical trials with larger sample size and better designation are required.

Rose oil in combination with other essential oils also showed beneficial effects in 
reducing menstrual pain and bleeding (Marzouk et al., 2013; Kim et al., 2011). A double-blind placebo controlled clinical trial compared the effects of rose oil inhalation with inhalation of almond oil. The results demonstrated reduction in postoperative pain in 32 3-6-year old children without any significant side effects (Marofi et al., 2015). The possible mechanisms for reducing pain by rose oil inhalation are stimulating the olfactory system, increasing parasympathetic activity, releasing neurotransmitters such as enkephalin and endorphin as well as reducing sympathetic activity and the release of cortisol and noradrenalin (Ikei et al., 2014; Lee et al., 2011; Park et al., 2007; Tsunetsugu et al., 2007). Different therapeutic properties of rose oil have been investigated in human studies and the most important of them are analgesic and anti-depressant activities. No side effects have been reported from rose oil in investigated human studies. According to Persian Medicine, some other pharmacological activities including anti-inflammatory and antihemorrhoidal properties have been attributed to this oil; however, no clinical trial has been focused on these activities yet. So, it is suggested to design clinical studies to evaluate these pharmacological activities. Furthermore, more research with higher populations is recommended to investigate the efficacy and safety of treatment with rose oil. (Mohebitabar et al., 2017).

The mechanism of action of inhaled aromatherapy starts with the absorption of volatile molecules through the nasal mucosa. Odor molecules are then transformed into chemical signals, which move towards the

\section{References}

Ayan, M., Tas, U., Sogut, E., Suren, M., Gurbuzler, L., Koyuncu, F. (2013). Investigating the effect of aromatherapy in patients with renal colic. J Altern Complement Med. 19(4), pp.329-33. doi:10.1089/acm.2011.0941. Epub 2012 Oct 16.

Batjun, M.T. (2015). Pengaruh Rendam Kaki Air Hangat Terhadap Penurunan Tekanan Darah Pada Lansia Penderita Hipertensi Di Wilayah Kerja Puskesmas Kecamatan Kebun Jeruk Jakarta Barat. Jurnal Keperawatan.

Black,J.M., dan Hawks,J.H.(2005). Medical Surgical Nursing. New York. Elsevier olfactory bulb, and possibly other parts of the limbic system, interacting with the neuropsychological framework to produce characteristic physiological and psychological effects.

It has been demonstrated that essential oils can be absorbed into the body via the skin or the olfactory system (Dye,1997; Tisserand,1996). Many studies found that olfactory stimulation by essential oils could produce instant changes in physiological parameters including muscle tension, blood pressure (BP), pulse rate, skin temperature, skin blood flow, electrodermal activity, and brain activity (Diego et al., 1998; Field et al., 2005; Lorig and Schwartz, 1988; Tisserand, 1996; Van Toller et al., 1993). Table 1 shows a summary of these studies. In addition to conventional therapy, inhalation of the fragrance of rose essential oil by eighty patients with renal colic in the emergency room, effectively reduced renal colic pain (Ayan et al., 2013). It was found that massage with rose oil reduces the severity of primary dysmenorrhea compared to massage therapy alone in 75 students (Sadeghi Aval Shahr et al., 2015).

\section{Conclusion}

In conclusion we can state that there was potential effect of a rose aromatherapy on reducing pain intensity in postoperative patients. It can be assumed this study would provide an outline towards the pain management for nursing intervention in dealing with pain complaints in postoperative patients.

Brunner \& Suddarth, (2002). Buku Ajar Keperawatan Medikal Bedah, alih bahasa: Waluyo Agung., Yasmin Asih., Juli., Kuncara., I.made karyasa, EGC, Jakarta.

Datak, G. (2008). Efektifitas Relaksasi Benson Terhadap Nyeri Pasca Bedah Pada Pasien Transurethral Resection of The Prostate Di Rumah Sakit Umum Pusat Fatmawati Jakarta. Retrieved from http://lib.ui.ac.id/file?file=digital/2016-10/20437530-Gad Datak.pdf

Diego, M. A., Jones, N. A., Field, T., Hernandez- Reif, M., Schanberg, S., Kuhn, C., McAdam, V., Galamaga, R., \& Galamaga, M. (1998). Aromatherapy positively affects mood, EEG patterns of alertness and math computations. 
International Journal of Neuroscience. 96 (3-4), pp. 217-224.

Dye, J. (1997). Aromatherapy for women \& childbirth. Saffron Walden, UK: The CW Daniel Company LTD.

Field, T., Diego, M., Hernandez-Reif, M., Cisneros, W., Feijo, L., Vera, Y., Gil, K., Grina, D., \& Claire He, Q. (2005). Lavender fragrance cleansing gel effects on relaxation. International Journal of Neuroscience. 115(2), pp. 207-222.

Ikei H, Komatsu M, Song C, Himoro E, Miyazaki Y. (2014). The physiological and psychological relaxing effects of viewing rose flowers in office workers. J Physiol Anthropol, 33(6), pp.11.

Kim, Y.J., Lee, M.S., Yang, Y.S., Hur, M.-H. (2011). Selfaromatherapy massage of the abdomen for the reduction of menstrual pain and anxiety during menstruation in nurses: a placebo-controlled clinical trial. Eur J Integr Med. 3, e165-e168.

Lee J, Park BJ, Tsunetsugu Y, Ohira T, Kagawa T, Miyazaki Y. (2011). Effect of forest bathing on physiological and psychological responses in young Japanese male subjects. Public health. 125, pp.93-100.

Lo, S. H., Chau, J. P., Woo, J., Thompson, D. R. \& Choi, K. C. (2016). Adherence to Antihypertensive Medication in Older Adults with Hypertension. The Journal of Cardiovascular Nursing. 31(4), pp 296-303.

Lorig, T. S., \& Schwartz, G. E. (1988). Brain and odor: I. Alteration of human EEG by odor administration. Psychobiology. 16, pp. 281-284.

Marofi, M, Sirousfard, M, Moeini, M, Ghanadi, A. (2015). Evaluation of the effect of aromatherapy with Rosa damascena Mill. on postoperative pain intensity in hospitalized children in selected hospitals affiliated to Isfahan University of Medical Sciences in 2013: A randomized clinical trial. Iran J Nurs Midwifery Res. 20, pp. 247-254.

Marzouk, T.M.F., El-Nemer, A.M.R., Baraka, H. N. (2013). The effect of aromatherapy abdominal massage on alleviating menstrual pain in nursing students: A prospective randomized cross-over study. Evid Based Complement Alternat Med. Article ID 742421.

Mohebitabar, S., Shirazi, M., Bioos, S., Rahimi, R., Malekshahi, F., \& Nejatbakhsh, F. (2017). Therapeutic Efficacy of Rose Oil: A Comprehensive Review of Clinical Evidence. Avicenna Journal of Phytomedicine, 7(3), pp. 206-213.

Ni, C. H., Hou, W. H., Kao, C. C., Chang, M. L., Yu, L. F., Wu, C. C. \& Chen, C. (2013). The Anxiolytic Effect of Aromatherapy on Patients Awaiting Ambulatory Surgery: A Randomized Controlled Trial. Evidence-Based Complementary and Alternative Medicine, Pages 5.

Park, B.J., Tsunetsugu, Y., Kasetani, T., Hirano, H., Kagawa, T., Sato, M., et al. (2007). Physiological effectsInt J Adv Life Sci Res. 2(1), 01-10 of Shinrin-yoku (taking in the atmosphere of the forest)-- using salivary cortisol and cerebral activity as indicators. J Physiol Anthropol. 26, pp.123- 128.
Potter P. Perry A. (2012). Fundamentals of Nursing. 8th ed. Mosby Co, United States.

Sadeghi, Aval Shahr, H., Saadat, M., Kheirkhah, M., \& Saadat, E. (2015). The Effect of Self- Aromatherapy Massage of the Abdomen on the Primary Dysmenorrhoea. Journal of Obstetrics and Gynaecology. 35(4), pp. 382385.

Shirazi, M., Mohebitabar, S., Bioos, S., Yekaninejad, M. S., Rahimi, R., Shahpiri, Z. \& Nejatbakhsh, F. (2017). The Effect of Topical Rosa damascena (Rose) Oil on Pregnancy-Related Low Back Pain: A Randomized Controlled Clinical Trial. Journal of Evidence-Based Complementary \& Alternative Medicine. 22(1), pp 120-126.

Lakhan, S. E., Sheafer, H., \& Tepper, D. (2016). The Effectiveness of Aromatherapy in Reducing Pain: A Systematic Review and Meta-Analysis. Pain Research and Treatment. 8158693. doi: 10.1155/2016/8158693.

Sikorski, C., Luppa, M., König, H. H., van den Bussche, H., \& Riedel-Heller, S. G. (2012). Does GP training in depression care affect patient outcome? - A systematic review and meta- analysis. BMC health services research. 12, 10. doi:10.1186/1472-6963-12-10

Suzanne C.Smeltzer \& Brenda G.Bare (2002) Buku Ajar Keperawatan Medikal Bedah Brunner \& Suddarth. Jakarta EGC. Ed.8 vol.3 cet.1 3. http://kin.perpusnas.go.id/DisplayData.aspx?pld=439\&pRe gionCode=JIPKMAL\&pClientld $=111$

Suriya, M. (2017). Hubungan Mobilisasi Dini dengan Proses Penyembuhan Luka Pada Post Operasi di Rs. TK III Dr. Reksodiwiryo Padang Tahun. The Shine Cahaya Dunia D-lii Keperawatan. 2(2), pp. 26-33.

Schwartz, R. K. (1979). Olfaction and muscle activity: An EMG pilot study. American Journal of Occupational Therapy., 33(3), pp.185-192.

Tisserand, M. (1996). Aromatherapy for woman, A practical guide to essential oils for health and beauty. Rochester, VT, Canada: Healing Arts Press.

Tsunetsugu, Y., Park, B.J., Ishii, H., Hirano, H., Kagawa, T., Miyazaki, Y. (2007). Physiological effects of Shinrinyoku (taking in the atmosphere of the forest) in an oldgrowth broadleaf forest in Yamagata Prefecture, Japan $\mathrm{J}$ Physiol Anthropol, 26, pp.135-142.

Van Toller, S., Behan, J., Howells, P., Kendal-Reed, M., \& Richardson, A. (1993). An analysis of spontaneous human cortical EEG activity to odours. Chemical Senses. 18, pp.1-16. 